\title{
2. A különleges jogrend nemzetközi jogi dimenziói az emberi jogok derogációja tükrében
}

\section{BÉRES NÓRA}

\section{Bevezetés}

Noha a különleges jogrendre vonatkozó szabályok főként az államok belső jogában lelhetők fel, valamint az is a nemzeti jogalkotó által választott alkotmányjogi megoldások függvénye, hogy egy adott állam a különleges jogrend melyik modelljét alkalmazza, ${ }^{1}$ az ilyenkor elsődleges kérdésként felmerülő alapjog-korlátozás a nemzetközi emberi jogi szerződések alkalmazásával, illetve azok hatályának felfüggesztésével szorosan összefügg.

Így jelen fejezet témájának lehatárolása érdekében már rögtön e ponton szükséges bevezetni egy fogalmi különbségtételt, ez pedig nem más, mint az emberi jogok korlátozása és az emberi jogok alkalmazásának felfüggesztése közötti disztinkció. Általában véve elmondható, hogy az emberi jogokat tartalmazó nemzetközi szerződések kettős terminológiát alkalmaznak, és meghatározzák, hogy békeidôben milyen feltételek mellett lehetséges korlátozások alkalmazása. A korlátozások lehetőségének elsődleges oka az, hogy a legtöbb emberi

I Így például míg a kontinentális jogcsaládba tartozó európai államok a dichotóm modellt alkalmazzák, addig az Amerikai Egyesült Államok a monista modellt követi (bővebben lásd az Egyesült Államokról szóló 26. fejezetet).

Dr. Béres Nóra, PhD, LLM

nora.beres@mfi.gov.hu

kutató (Mádl Ferenc Összehasonlító Jogi Intézet)

tanársegéd (Miskolci Egyetem Állam- és Jogtudományi Kar, Európai és Nemzetközi Jogi Intézet)

Béres, N. (2021) 'A különleges jogrend nemzetközi jogi dimenziói az emberi jogok derogációja tükrében' in Nagy, Z., Horváth, A. (szerk.) A különleges jogrend és nemzeti szabályozási modelljei, 37-51. o. Budapest: Mádl Ferenc Összehasonlító Jogi Intézet.




jog nem abszolút, hanem sokkal inkább az egyén és a közösség érdeke közötti érzékeny balansz megtestesítője. ${ }^{2}$ Ezzel párhuzamosan ugyanakkor az is jellemző, hogy e szerződések rögzítik a jogok nem garantálásának, azaz az eltérés jogának, a derogációnak a lehetőségét is. ${ }^{3} \mathrm{Az}$ alapjog-korlátozás és a derogáció fogalma közé tehát nem tehetünk egyenlőségjelet: az eltérés joga azt jelenti, hogy az e szerződésekben részes államok számára szigorúan meghatározott anyagi jogi és eljárásjogi feltételek betartása mellett lehetőségük nyílik rá, hogy különleges jogrend idején bizonyos nemzetközi emberi jogi kötelezettségvállalásaik alól ideiglenesen mentesüljenek. Ennek pedig az a legfontosabb gyakorlati következménye, hogy az eltérés jogával élő államot a derogációval érintett szerződéses cikkek megsértéséért később nem lehet felelősségre vonni. ${ }^{4} \mathrm{~A}$ derogációval kapcsolatban fontos továbbá megjegyezni, hogy az abszolút jogok ${ }^{5}$ alkalmazásától különleges jogrend idején sem lehet eltérni, azaz az ilyen jogok nem derogálhatók.

E fejezet konkrét tárgyát két derogációs klauzula vizsgálata képezi, amelyek a Polgári és Politikai Jogok Nemzetközi Egyezségokmányának ${ }^{6}$ (a továbbiakban: PPJNE vagy Egyezségokmány) 4. cikke, ${ }^{7}$ valamint az Emberi Jogok Európai Egyezményének ${ }^{8}$ (a továbbiakban: EJEE vagy Egyezmény) 15. cikke.9 Utóbbiak kiválasztásának egyértelmú oka az volt, hogy

2 Daes, 1983, 183. o.

3 Gárdos-Orosz, 2018, 29-30. o.

$4 \mathrm{Az}$ persze már más kérdés, hogy ha az eltérés jogát biztosító szerződéses cikket sérti meg a részes állam, például úgy, hogy a különleges jogrend kihirdetésének feltételei nem állnak fenn. E kérdésről részletesebben lásd késóbb e fejezetet.

5 Ilyenek például az élethez való jog, a kínzás tilalma, a rabszolgaság és szolgaság tilalma vagy a visszaható hatály alkalmazása a büntetőjogban.

6 1976. évi 8. törvényerejü rendelet az Egyesült Nemzetek Közgyülése XXI. ülésszakán, 1966. december 16-án elfogadott Polgári és Politikai Jogok Nemzetközi Egyezségokmánya kihirdetéséről.

7 PPJNE 4. cikk (1) A nemzet létét fenyegető és hivatalosan kihirdetett szükségállapot idején az Egyezségokmányban részes államok az adott helyzet által szigorúan megkövetelt mértékben tehetnek olyan intézkedéseket, amelyek eltérnek az Egyezségokmányban vállalt kötelezettségeiktől, feltéve, hogy az ilyen intézkedések nem állnak ellentétben egyéb nemzetközi jogi kötelezettségeikkel, és nem jelentenek kizárólag faj, szín, nem, nyelv, vallás vagy társadalmi származás alapján történő megkülönböztetést.

(2) E rendelkezés alapján nem lehet eltérni a 6., 7., 8. (1. és 2. bekezdés), 11., 15., 16. és 18. cikktől.

(3) Az Egyezségokmányban részes minden állam, amely él az eltérés jogával, az Egyesült Nemzetek fótitkára útján haladéktalanul tájékoztatni köteles az Egyezségokmányban részes többi államot azokról az intézkedésekről, amelyektől eltért, és azokról az okokról, amelyek erre késztették. További tájékoztatást kell adni ugyanezen az úton arról az időpontról, amikor az állam az ilyen eltéréseknek véget vet.

8 1993. évi XXXI. törvény az emberi jogok és az alapvető szabadságok védelméről szóló, Rómában, 1950. november 4-én kelt Egyezmény és az ahhoz tartozó nyolc kiegészítő jegyzőkönyv kihirdetéséről.

9 EJEE 15. cikk (1) Háború vagy a nemzet létét fenyegető más rendkívüli állapot esetén bármely Magas Szerződő Fél a jelen Egyezményben meghatározott kötelezettségeitől eltérő intézkedéseket tehet a helyzet szükségessége által feltétlenül megkívánt mértékben, feltéve, hogy az ilyen intézkedések nem ellentétesek egyéb nemzetközi jogi kötelezettségeivel.

(2) E rendelkezés alapján nem lehet eltérni a 2. cikk rendelkezéseitől, kivéve a jogszerú háborús cselekmények következtében okozott haláleseteket, vagy a 3. cikk, 4. cikk (1. bekezdés), valamint a 7. cikk rendelkezéseitől. (3) Az eltérés jogával élő Magas Szerződő Fél az Európa Tanács főtitkárának teljes körű tájékoztatást ad az általa tett intézkedésekről és azok okairól. Ugyancsak tájékoztatja az Európa Tanács fótitkárát, amikor az ilyen intézkedések hatályukat vesztették, és az Egyezmény rendelkezéseit ismét teljes mértékben végrehajtják. 
Magyarország - és az e könyvben bemutatott legtöbb ország - mindkét szerződésnek részes állama, így az ezekben foglalt rendelkezések hazánkat - és persze a többi országot is kötik..$^{10}$

Továbbá megjegyzendő, hogy napjainkban a derogációs klauzulák alkalmazása a koronavírus-járvánnyal kapcsolatban a világ számos országában bevezetett különleges jogrend miatt mind a PPJNE, mind az EJEE vonatkozásában ${ }^{11}$ különös jelentőséggel bír, tekintve, hogy az államok is a szokásosnál jóval gyakrabban kívántak az eltérés jogával élni. Az Európa Tanács nyilvántartása szerint például idáig tíz állam (Albánia, Észak-Macedónia, Észtország, Grúzia, Lettország, Moldova, Örményország, Románia, San Marino és Szerbia) nyújtott be az EJEE 15. cikk (3) bekezdése szerinti nyilatkozatot az Európa Tanács fốtitkárához. ${ }^{12}$ Mindemellett persze megjegyzendő, hogy az EJEE 15. cikkére való hivatkozás előtt, illetve a notifikáció elmaradása esetén az alapjogok korlátozása a szükségesség/arányosság tesztje alapján is alátámasztható a nem abszolút jogok esetén. ${ }^{13}$

\section{A Polgári és Politikai Jogok Nemzetközi Egyezségokmányának 4. cikke}

A PPJNE egyfajta primus inter pares szerepet tölt be az univerzális nemzetközi emberi jogi szerződések között. Részes államainak száma 2020. december 15-én 173, ${ }^{14}$ amely a nemzetközi közösség egészét tekintve tekintélyes számnak mondható. Ebből is adódik, hogy az Egyezségokmányban foglalt kötelezettségek univerzális természetúek, azon kevés állam számára pedig, amelyek nem részes felei a PPJNE-nek, a szokásjog és a múvelt nemzetek által elismert jogelvek bizonyítékaként szolgálnak.

10 A PPJNE és az EJEE mellett az Emberi Jogok Amerikai Egyezménye (27. cikk) és az Európai Szociális Charta (30. cikk) tartalmaz még derogációs klauzulát. Lásd: American Convention on Human Rights, opened for signature Nov. 22, 1969, 1144 U.N.T.S. 123, entered into force July 18, 1978; 1999. évi C. törvény az Európai Szociális Charta kihirdetéséről.

11 Az eltérés jogával élő államok naprakész listái megtalálhatók a United Nations Treaty Collections, valamint a Treaty Office of the Council of Europe honlapján: https://treaties.un.org/Pages/ViewDetails. aspx?chapter=4\&clang=_en\&mtdsg_no=IV-4\&src=IND; www.coe.int/en/web/conventions/full-list/-/conventions/webContent/62111354 (Letöltve: 2020 . december 15.).

12 Lásd bővebben: Istrefi, 2020.

13 Till, 2020, 41-52. o. European Court of Human Rights, Guide on Article 15 of the European Convention on Human Rights, Derogation in Time of Emergency. Elérhető: www.echr.coe.int/Documents/Guide_Art_15_ENG.pdf (Letöltve: 2020 . december 15.).

14 United Nations Treaty Collections, International Covenant on Civil and Political Rights. Elérhető: https:// treaties.un.org/Pages/ViewDetails.aspx?src=TREATY\&mtdsg_no=IV-4\&chapter=4\&clang=_en (Letöltve: 2020. december 15.). 
A PPJNE kontrollmechanizmusát ${ }^{15}$ háromféle eljárás keretében látja el az Emberi Jogok Bizottsága (a továbbiakban: Bizottság). ${ }^{16} \mathrm{Az}$ első a részes államok periodikus írásbeli jelentéseinek vizsgálata az Egyezségokmány átültetéséről, amelyek keretében a Bizottság egyfajta konstruktív párbeszédet folytat az állammal, és erről jelentést küld az ENSZ Közgyúlésének. Ez a Bizottság egyik legfontosabb feladata, azaz a tagállamok belső jogának monitoringja, így többek között a 4. cikk megfelelő átültetésének vizsgálata is. ${ }^{17} \mathrm{Az}$ államok a Bizottságnak megküldött periodikus jelentésekben kötelesek tájékoztatást nyújtani az esetlegesen kihirdetett különleges jogrend idején történő jogalkotásról és jogalkalmazásról, ami eredményében egyfajta összehasonlító analízis kialakulásához vezet. Ilyen vizsgálatra példaként a Bizottság egyik 2001. évi jelentése hozható, amelyben a Bizottság aggodalmát fejezte ki Horvátország alkotmányának különleges jogrendre vonatkozó 17. cikke miatt, mert az nem felelt meg az Egyezségokmány 4. cikkében foglaltaknak: a különleges jogrend kihirdetése nem csak a „nemzet létét fenyegető szükségállapot idején” és az Egyezségokmány által meghatározott „szigorúan megkövetelt mértékben” történhetett, továbbá Horvátország alkotmánya az abszolút jogok között a PPJNE 8. cikk (1)-(2) bekezdését, 11. cikkét és 16. cikkét nem szerepeltette. ${ }^{18}$ Ugyanabban az évben a Bizottság ${ }^{19}$ a guetamalai helyzet miatt is aggodalmának adott hangot, mivel az ország alkotmányos szabályai a PPJNE-ben foglalt kötelezettségek hatálybaléptetésének gátat szabtak, tekintve, hogy a személyi elven alapuló joghatóság-gyakorlást csak a hadsereg tagjai felett alkalmazták, illetőleg nem ismerték el az őslakosok egyes jogait.

A második eljárástípus az egyéni panasz kivizsgálása abban az esetben, ha az állam ratifikálta a PPJNE Első Kiegészítő Jegyzőkönyvét is ${ }^{20}$ - ilyenkor az eljárás nem kötelező állásfoglalással zárul. A kontrollmechanizmus harmadik típusú eljárása az állam kontra állam panaszok kivizsgálása akkor, ha az állam a PPJNE 41. cikke ${ }^{21}$ szerinti nyilatkozattal ehhez külön hozzájárult, ám mivel a Bizottság a PPJNE 4. cikkének értelmezésével az első kettő eljárási formában foglalkozott, a harmadik eljárástípust a továbbiakban nem vizsgáljuk.

15 Lamm, 2018, 225-231. o.; Kovács, 2016, 373. o.; Joseph-Castan, 2013, 622-633. o.

16 A magyar nyelvû szakirodalom a Human Rights Committee-t néhol Emberi Jogi Bizottságnak, néhol Emberi Jogok Bizottságának fordítja. E fejezetben a PPJNE 28. cikkét alapul véve az Emberi Jogok Bizottsága terminológiát alkalmazzuk. Lásd még: Kovács, 2016, 373. 0.

17 UN Doc. A/46/40, \$\$ 56-58, 99.

18 UN Doc. A/56/40, Vol. I, \$80(9).

19 UN Doc. A/56/40, Vol. I, \$ 85(10)-(11).

$20 \mathrm{Az}$ Első Kiegészítő jegyzőkönyvnek 2020. december 15-én 116 részes állama van. Lásd: uo.

21 PPJNE 41. cikk (1) Az Egyezségokmányban részes bármelyik állam e cikk alapján bármikor kijelentheti, hogy elismeri a Bizottság arra vonatkozó illetékességét, hogy az átvegyen és megvizsgáljon olyan bejelentéseket, amelyekben valamely részes állam azt állítja, hogy egy másik részes állam nem teljesíti az Egyezségokmányban foglalt kötelezettségeit. Az ennek a cikknek az alapján történő bejelentéseket csak az esetben lehet elfogadni és megtárgyalni, ha azok olyan részes államtól származnak, amely kijelentette, hogy saját magára nézve elismeri a Bizottság illetékességét. A Bizottság nem vesz át olyan bejelentést, amelyben olyan részes állam érdekelt, amely nem tett ilyen kijelentést. 
A 4. cikk a PPJNE kulcsfontosságú rendelkezése, amelynek tárgyi hatálya minden bizonnyal az emberi jogokat leginkább kihívás elé állító helyzetekre terjed ki. ${ }^{22} \mathrm{E}$ cikkel kapcsolatban elsőként tehát azt érdemes tisztáznunk, hogy pontosan milyen esetkörökre vonatkozik. A PPJNE úgy fogalmaz, hogy a nemzet létét fenyegető szükségállapot ${ }^{23}$ a 4 . cikk alkalmazásának szükségszerú előfeltétele. Jóllehet a Bizottság a szükséghelyzet egzakt definícióját nem alkotta meg, annyit leszögezett, hogy „nem minden zavargás vagy katasztrófa minősül a nemzet létét fenyegető szükségállapotnak a 4. cikk (1) bekezdés alapján”. ${ }^{24}$ Továbbá példálózó jellegû felsorolást is olvashatunk a 4. cikk 2001. évi általános kommentárjában, amely szerint a nemzetközi és a nem nemzetközi fegyveres konfliktusok, a természeti katasztrófák, a tömeges és erőszakos tüntetések vagy a súlyos ipari katasztrófák ilyennek minősülhetnek. ${ }^{25}$ Így például 1989-ben Kanada pusztító erdőtüzek miatt hivatkozott az Egyezségokmányban definiált nemzet létét fenyegető szükségállapotra, ${ }^{26}$ míg Spanyolország terrorveszéllyel indokolva. ${ }^{27} \mathrm{~A}$ háború, amely értelemszerủen tartalmilag szintén beletartozik a nemzet létét fenyegető szükségállapot kategóriájába, az EJEE 15. cikkétől eltérően nincs önállóan nevesítve a PPJNE 4. cikke alatt. E terminológiát per se ugyanis az Egyezségokmány szándékosan kerüli, minthogy az ENSZ felállításának egyik eredendő célja a béke fenntartása és a háborúk megelőzése volt, s emiatt jobbnak látták az alapító tagállamok, hogy a háború kifejezést az ENSZ-dokumentumokban még az említés szintjéról is számúzik. ${ }^{28} \mathrm{~A}$ háborútól eltérően a gazdasági válság önmagában nem szolgáltathat okot a nemzet létét fenyegető szükségállapotra, ám következményei már megállhatják a helyüket. Erre jó példa Ecuador, ahol 2001-ben az országot sújtó gazdasági válság következtében kialakult belsô zavargások vezettek egy hétig tartó különleges jogrend bevezetéséhez. ${ }^{29}$

Továbbá a 4. cikk (1) bekezdése alapján az is a szükségállapot fennállásának követelménye, hogy ez a helyzet a nemzet létét veszélyeztesse, amely kitétel egyértelmúen a részes államok hatalommal való visszaélésének kiiktatását célozza meg. E ponton érdekességként megjegyzendő, hogy az EJEE 15. cikke szó szerint ugyanezt a terminológiát alkalmazza, amelynek értelmezésére az Emberi Jogok Európai Bíróságának (a továbbiakban: EJEB vagy Bíróság) a Lawless kontra Irország ügyben hozott ítéletét tekinthetjük irányadónak. Eszerint

22 Nowak, 2005, 72-93. o.

23 Itt kívánjuk megjegyezni, hogy a PPJNE 4. cikkének hiteles magyar nyelvú fordításában a public emergency kifejezés szükségállapotként szerepel, ezzel szemben az EJEE 15. cikkének szintén hiteles magyar nyelvú fordításában a rendkívüli állapotot nevesíti. Lásd az Egyesült Nemzetek Közgyúlése XXI. ülésszakán, 1966. december 16-án elfogadott Polgári és Politikai Jogok Nemzetközi Egyezségokmánya kihirdetéséről szóló 1976. évi 8. törvényerejû́ rendeletet, valamint az emberi jogok és az alapvető szabadságok védelméről szóló, Rómában, 1950. november 4-én kelt Egyezmény és az ahhoz tartozó nyolc kiegészítő jegyzőkönyv kihirdetéséről szóló 1993. évi XXXI. törvényt.

24 UN Doc. A/56/40, Vol. I, 202, \$3.

25 UN Doc. A/56/40, Vol. I, 202, \$3, 5.

26 UN Doc. A/46/40, \$59.

27 UN Doc. A/46/40, \$150-152.

28 UN Doc. A/2929, \$39.

29 UN Doc. A/56/40, Vol. I, \$ 33 . 
a nemzet létét veszélyeztető szükségállapot olyan, „az egész lakosságot érintő krízishelyzet vagy szükségállapot, mely az államalkotó közösség szervezett életét veszélyezteti”. ${ }^{30} \mathrm{~A}$ szervezett élet veszélyeztetése mind a lakosság, mind a területi integritás, mind pedig az államszervek kitettségében megnyilvánulhat. Az elsőre példaként hozható fel, hogy 2001-ben Guatemala azért folyamodott derogációhoz, mert 27 különösen veszélyesnek nyilvánított fogvatartott megszökött egy büntetés-végrehajtási intézetből, akiknek a bírósági tárgyalása során tanúként sok embert hallgattak ki, és az ő életüket féltve a nemzet létét veszélyeztető szükségállapot kihirdetése mellett döntöttek. ${ }^{31}$ Ami a területi integritást illeti, szintén 2001-ben Szudán „az egyes régiókban uralkodó kivételes körülményekre” hivatkozva hirdetett különleges jogrendet, mivel a humanitárius katasztrófába torkolló etnikai ellenségeskedések $^{32}$ az ország stabilitását és biztonságát veszélyeztették. ${ }^{33}$

A belső jogi terminológia ugyanakkor nem lényeges a 4. cikk (1) bekezdés alkalmazása szempontjából, azaz nem szükséges, hogy a különleges jogrend szükségállapotként kerüljön kihirdetésre. A PPJNE 4. cikke szerint megállja a helyét az is, ha ostromállapotot (Argentína, Bolívia, Kolumbia), ${ }^{34}$ riasztást (Spanyolország), ${ }^{35}$ gazdasági szükségállapotot (Nicaragua), ${ }^{36}$ hadiállapotot (Finnország) ${ }^{37}$ vagy nemzeti szükségállapotot (Madagaszkár) ${ }^{38}$ hirdetnek ki, a lényeg sokkal inkább a tartalomban rejlik: az elnevezés helyett lényegesebb, hogy a derogáció kivételes és ideiglenes természetû legyen, ${ }^{39}$ tehát az, hogy amint a nemzet léte már nincs veszélyben, haladéktalanul vissza kell térni a „békebeli” szabályozáshoz.

Az Egyezségokmányban biztosított eltérés jogának az is előfeltétele, hogy a szükségállapotot hivatalosan is ki kell hirdetni. E kritérium egyértelmúen a törvényesség és jogállamiság elveinek erősítésére hivatott azokban az időkben, amikor arra éppen a leginkább szükség van. A kihirdetés az átláthatóság elsődleges eszköze, az önkényes derogáció és a de facto különleges jogrend garanciális ellensúlya. Bár szintén az EJEB esetjogából való merítésről van szó, anélkül, hogy előre kívánnánk szaladni, a Branningan \& MacBride kontra Egyesült Királyság ${ }^{40}$ ügyet már e ponton is érdemes megemlíteni. Az eset tényállása szerint a panaszosok beadványukban azt sérelmezték, hogy az Egyesült Királyság soha nem hirdetett ki hivatalosan szükségállapotot az észak-írországi terrorveszéllyel összefüggésben, amivel szemben az alperes állam azzal védekezett, hogy a belügyminiszter a képviselőházban formálisan

30 Lawless v. Ireland, ECtHR, (Ser. A) No. 3 (1961), \$ 28.

31 UN Doc. A/56/40, Vol. I, \$34.

32 Lásd bővebben: Béres, 2020, 59-65. o.

33 UN Doc. A/57/40, Vol. I, \$ 32 .

34 UN Doc. A/45/40, Vol. I, \$ 219; UN Doc. A/57/40, Vol. I, \$34 (Argentína); UN Doc. A/52/40, Vol. I, \$204 (Bolívia);

UN Doc. CCPR/C/SR.222, \$3 (Kolumbia).

35 UN Doc. CCPR/C/SR.142, \$5.

36 UN Doc. CCPR/C/SR.442, \$7.

37 UN Doc. CCPR/C/SR.170, \$84.

38 UN Doc. CCPR/C/SR.83, \$27; UN Doc. CCPR/C/SR.84, \$11.

39 UN Doc. A/56/40, \$2.

40 Branningan \& MacBride v. United Kingdom, ECtHR, (Ser. A) No. 539 (1993), § 17. 
bejelentette a különleges jogrendet. A Bíróság ezen érvelésnek helyt adott, a panaszosok beadványát pedig elutasította, mert a belügyminiszter parlamentben tett szóbeli nyilatkozatát elég hivatalosnak és nyilvánosnak találta, az EJEE 15. cikkében foglalt derogáció jogszerüségéhez szükséges mértékủnek..$^{41}$ Azt sem az EJEE, sem a PPJNE nem határozza meg, hogy a hivatalos kihirdetésre melyik állami szervnek van hatásköre. Ez utóbbi a gyakorlatban az állam alkotmányos berendezkedésének függvénye. Mindazonáltal kétséges lehet, hogy erre egyetlen személynek, például az uralkodónak, az elnöknek, a miniszterelnöknek vagy a haderő fôparancsnokának juttatott hatáskör elegendő garanciát nyújt-e. ${ }^{42}$

Az Egyezségokmány 28. cikk (1) bekezdése által felállított Bizottság a 4. cikkel az Első Kiegészítő Jegyzőkönyv által biztosított egyéni panaszeljárás keretében foglalkozott a legtöbbet, például Uruguay kapcsán az 1970-es és az 1980-as években. Így például a Ramirez kontra Uruguay ${ }^{43}$ ügyben kimondta, hogy hivatalból vizsgálhatja a 4. cikk alkalmazhatóságát akkor is, ha a részes állam konkrétan nem hivatkozott rá. Emellett a Bizottság a Silva kontra Uruguay $^{44}$ ügyben hozott állásfoglalásában azt is javasolta, hogy ha egy részes állam a derogációt az Egyezségokmány 4. cikk (1)-(2) bekezdései alapján igazolni tudja, akkor az, hogy a 4. cikk (3) bekezdése szerinti tájékoztatási kötelezettségének nem tett eleget, még nem zárja ki, hogy a derogáció alátámasztásához érvényes kimentési okot szolgáltasson. A derogáció Egyezségokmányban meghatározott feltételeinek bizonyítása az egyéni panaszeljárásokban a részes államot terheli. Noha a Bizottság az államok szuverén jogát a szükségállapot kihirdetésére elismeri, kontrollmechanizmusként funkcionál a nemzeti mérlegelés jogszerúsége felett. ${ }^{45}$ Ez a megközelítés ugyanakkor némileg elsiklik az EJEB joggyakorlata mellett, amely az Írország kontra Egyesült Királyság ${ }^{46}$ ügyben úgy foglalt állást, hogy elsősorban a részes államok mérlegelési szabadságába esik a szükségállapot nemzet létét veszélyeztetô jellegének meghatározása, és ha e szükségállapot elrendelésre került, akkor utána az is, hogy az ultima ratióként alkalmazott jogrendben bevezetett eszközökkel meddig lehet elmenni a szükségállapot leküzdése érdekében.

A PPJNE azt is lehetővé teszi részes államai számára, hogy az emberi jogok korlátozásával válaszoljanak különleges helyzetekre derogáció helyett, ${ }^{47}$ ráadásul a korlátozásra és a derogációra vonatkozó alapelvek között átfedések lehetnek, úgymint például a szükségesség, az arányosság, a diszkrimináció tilalma vagy egyéb nemzetközi jogi kötelezettségek tiszteletben tartása [az arányosság és a diszkrimináció tilalma a PPJNE 4. cikk (1) bekezdé-

41 Uo. $\$ \$ 72-73$.

42 McGoldrick, 2003, 380-429. o.

43 UN Doc. A/35/40, \$121.

44 UN Doc. A/36/40, \$130.

45 Maroufidou v. Sweden, UN Doc. A/36/40, 160, \$\$ 10.1-10.2; Aumeeruddy-Cziffra v. Mauritius, UN Doc. A/36/40, 134, \$ 9.2(b)2(ii)3; Hammel v. Madagascar, UN Doc. A/42/40, 130, \$ 20; V.R.M.B. v. Canada, UN Doc. $\mathrm{A} / 43 / 40,258, \$ 6.3$.

46 Republic of Ireland v. United Kingdom, ECtHR, (Ser. A) No. 25, (1978), \$ 207.

47 Kiss, 1980, 290. o. 
sének szövegéből egyenesen következik]. Az államok pedig sok esetben veszélyhelyzet esetén sem élnek a derogáció lehetőségével, hanem a jogkorlátozás keretein belül maradva próbálnak meg reagálni a különleges helyzetek által előidézett kihívásokra. A PPJNE úgyszintén ezt a logikát sugallja: amennyiben lehet, inkább jogkorlátozásra kerüljön sor, semmint derogációra. A gyakorlat is ezt támasztja alá, például Ciprus, Suriname, Mexikó vagy Irak ${ }^{48}$ a jogkorlátozás adta eszközökkel válaszolt az államban kialakult különleges helyzetekre.

Összegzésképpen tehát megállapíthatjuk: a PPJNE 4. cikke expressis verbis elismeri, hogy előfordulhat olyan szükséghelyzet, amikor az Egyezségokmányban foglalt jogok derogációja jogszerû. Amennyiben viszont a PPJNE részes állama erre a cikkre hivatkozik - mivel az Egyezségokmány ezen rendelkezése a részes felekre egyszersmind elsődleges kötelezettséget ró -, az állami felelősség által kínált kimentési okokra (például jogos önvédelemre vagy szükséghelyzetre) párhuzamosan már nem lehet hivatkozni. ${ }^{49}$ Hasonlóképpen, az is a 4 . cikk alkalmazásának egyik rendhagyó következménye, hogy a nemzetközi szerződések jogának főszabályára - miszerint egyetlen részes fél sem hivatkozhat belső jogának rendelkezéseire annak igazolásául, hogy elmulasztotta a szerződést teljesíteni (1969. évi Bécsi Egyezmény 27. cikk) $)^{50}$ - egyidejúleg nem lehet hivatkozni.

\section{Az Emberi Jogok Európai Egyezményének 15. cikke}

A PPJNE-hez hasonlóan az EJEE-nek is van derogációs klauzulája, mi több, e két derogációs klauzula szövegében nagyon hasonlít egymásra, néhány fordulata szó szerint megegyezik. Utóbbi okára az Egyezségokmány előkészítő anyagai (travaux préparatoires) egyértelmú válasszal szolgálnak, amelyekből megtudhatjuk, hogy noha a PPJNE csak 1966-ban került elfogadásra, a 4. cikk tervezetét már 1949-ben véglegesítették, s később ez a szövegváltozat került bele a 17 évvel késóbb aláírásra megnyitott dokumentumba. ${ }^{51} \mathrm{Az}$ 1950-ben elfogadott Egyezmény derogációs klauzuláját tehát a PPJNE 4. cikkének ezen 1949-es verziója ihlette, illetve később az Emberi Jogok Amerikai Egyezményének 27. cikkét is. ${ }^{52}$

A belső joghoz hasonlóan, a különleges jogrend definíciójának megalkotása a nemzetközi szerződésekben sem könnyú, sốt talán a magas számú állami konszenzusért kiáltó dokumentumokban e folyamat még sokkal nehezebb is. A szerződések megkötésének folyamatát gyakorta jellemző diplomáciai zsákutcákba szorulás mellett a derogációs klauzulák esetén

48 Ciprus UN Doc. A/34/40, \$383 (1979), Suriname UN Doc. A/35/40, \$2 297 (1980), Mexikó UN Doc. A/54/40, Vol. I, $\$ 324$, Irak UN Doc. A/46/40, \$\$ 618-56.

49 Crawford, 2002, 160-189. o.

50 Vienna Convention on the Law of Treaties, art. 27, May 23, 1969, 1155 U.N.T.S. 331, entered into force Jan. 27, 1980; 1987. évi 12. törvényerejű rendelet a szerződések jogáról szóló, Bécsben, az 1969. évi május hó 23. napján kelt szerződés kihirdetéséről.

51 El Zeidy, 2003, 279. o.

52 Lásd bővebben: Raisz, 2009. 
az is különösen nehéz, hogy a tervezett szöveg ne legyen túlzottan kiterjesztő, azaz ne adjon zöld utat az esetleges állami visszaéléseknek, mindazonáltal ne legyen túlzottan megszorító se, azaz képes legyen arra, hogy a különleges jogrendre okot szolgáltató helyzetek széles skáláját lefedje. Jobb híján a különleges jogrend definiálása egyfajta jogalkotó 'zsonglőrködésének' tekinthetô, ám itt a tét kétségkívül jelentős: olyan helyzetekre kell egy elasztikus fogalmat rászabni, amelyek egyáltalán nem láthatók előre, egyáltalán nem kiszámíthatók. ${ }^{53}$

Az Emberi Jogok Európai Bizottsága a nemzet létét fenyegető más rendkívüli állapot fogalmát először 1959-ben definiálta a már említett Lawless kontra Írország ügyben, miszerint: „olyan kivételes és közvetlen veszélyhelyzet vagy az egész lakosságot - nem pedig elkülönült csoportokat - sújtó válság, ami veszélyt jelent az államalkotó közösség szervezett életére". ${ }^{54}$ Végül azonban, mint ahogyan azt már fentebb is láthattuk, a Bíróság az ügyben meghozott ítéletében e fogalmat némileg árnyalta, és arra jutott, hogy a 15. cikk terminológiája alatt az államalkotó közösség szervezett életét veszélyeztető, az egész népességet érintő krízishelyzetet vagy szükségállapotot kell érteni. Tulajdonképpen ez utóbbi megállapítás lett az EJEB további esetjogának kiindulási alapja, amelynek eredeti, francia nyelvú szövegében nemcsak a „kivételes”, hanem a „közvetlen” jelző is szerepelt, ${ }^{55}$ így ezek jelentését fejlesztette később tovább az Emberi Jogok Európai Bizottsága az úgynevezett görög ügyekben. ${ }^{56}$

Az EJEE 15. cikke lehetővé teszi részes államainak, hogy számos, az Egyezményben szereplő emberi jog alkalmazásának hatályát felfüggesszék, ám ez utóbbi nyilván nem olyan egyszerû: a derogációs klauzulát csak pontosan meghatározott rendkívüli esetekben, szigorú standardok és konkrét eljárási lépések betartása mellett lehet „múködésbe hozni". ${ }^{57}$ A 15. cikk olvasata alapján megállapíthatjuk, hogy alkalmazása három együttes előfeltételhez kötött: háború vagy a nemzet létét fenyegető más rendkívüli állapot fennállása; a derogációnak a helyzet szükségessége által feltétlenül megkívánt mértéke; továbbá az így meghozott intézkedések a részes állam egyéb nemzetközi jogi kötelezettségeivel való összeegyeztethetősége.

Az EJEE 15. cikk alkalmazásának első kritériuma tehát a háború vagy a nemzet létét fenyegető más rendkívüli állapot fennállása. A PPJNE 4. cikk (1) bekezdésével ellentétben az EJEE 15. cikk (1) bekezdésében megjelenik a háború is a nemzet létét fenyegető más rendkívüli állapot ${ }^{58}$ mellett, lényegében véve a nemzet létét fenyegetô rendkívüli állapotok egyik

53 Hamilton, 1960, 153. o.

54 Lawless v. Ireland, 1 ECtHR (Ser. B), [1960-61] \$ 82.

55 Lawless v. Ireland, $\$ 28$.

56 3321/67 (Denmark v. Greece), 3322/67 (Norway v. Greece), 3323/67 (Sweden v. Greece), 3344/67 (Netherlands v. Greece).

57 El Zeidy, 2003, 282. o.

58 Érdekességként megjegyzendő, hogy míg a PPJNE 4. cikk (1) bekezdése szükségállapotot említ, addig az EJEE 15. cikk (1) bekezdésének magyar nyelvú fordításában rendkívüli állapot szerepel. Ez a terminológiai kettősség azonban az angol nyelvû szerződésekben nincs jelen, mindkét jogszabályhelyen az emergency kifejezést használták. 
eseteként. Az Emberi Jogok Európai Bizottsága a Lawless kontra Írország $g^{59}$ ügyben kimondta, hogy a háború e helyütt nem kell hogy a totális háborút jelentse, kevésbé átfogó jellegű fegyveres konfliktusok is idetartozhatnak, amennyiben a nemzet létét veszélyeztetik. ${ }^{60}$ Továbbá a görög ügyekben az Emberi Jogok Európai Bizottsága arra a következtetésre jutott, hogy az Egyezmény 15. cikk (1) bekezdése szerinti rendkívüli állapotnak ténylegesnek és közvetlennek kell lennie, az egész nemzet létét és a közösség szervezett életét kell veszélyeztetnie, továbbá szükséges, hogy az EJEE által biztosított rendes intézkedések és korlátozások többé már nem elegendőek a közbiztonság, a közegészség és a közrend fenntartásához. A ténylegesség és a közvetlenség ebben az esetben azt jelenti, hogy általános preventív jelleggel nem lehet a 15. cikkre hivatkozni, azaz a rendelkezés csak akkor hívható fel, ha a rendkívüli állapot már bekövetkezett, vagy haladéktalanul be fog következni.

Noha a Lawless kontra Írország ügyben alkalmazott értelmezés azt sugallta, hogy a rendkívüli állapotnak az egész nemzet életét kell veszélyeztetnie, e standardot későbbi esetjogában a Bíróság félretette. Ehelyett utóbb az Irország kontra Egyesült Királyság ügynek köszönhetően inkább az az álláspont vált elfogadottá, hogy az államterületnek csak egy részét sújtó események is veszélyeztethetik az egész nemzet létét, és ilyen esetekben a derogációt csupán ezen érintett területre kell alkalmazni. Tehát a rendkívüli állapot által előidézett veszélynek az egész nemzet létét kell érintenie, emellett ugyanakkor a veszélyforrásnak elegendő csak bizonyos területeken jelen lennie. ${ }^{61}$

A nemzet létét fenyegető más rendkívüli állapot fogalmának értelmezése során a Bíróság az A és mások kontra Egyesült Királyság ${ }^{62}$ ügyben hangsúlyozta az államok mérlegelési szabadságát a különleges jogrend kihirdetése vonatkozásában, és helyben hagyta a brit kormány arra irányuló érveit, hogy a 2001. szeptember 11-i terrortámadások után - noha akkoriban az Egyesült Királyságban semmiféle terrorcselekmény nem történt - különleges jogrendet hirdettek ki az Egyesült Államokkal való szoros kapcsolatra hivatkozva. Az EJEB ebben a döntésében az állam szabad mérlegelésének olyannyira teret engedett, hogy bár az Egyesült Királyságon kívül egyetlen részes állam sem jelezte derogációs szándékát a globális terrorveszélyre hivatkozva, jogszerűnek ítélte meg az Egyezménytől való eltérés alkalmazását. ${ }^{63}$

Az EJEE 15. cikk alkalmazásának második előfeltétele a derogációnak a helyzet szükségessége által feltétlenül megkívánt mértéke, ami talán a legjobban tükrözi a derogációs klauzula esszenciáját. A megkívánt mérték vizsgálatakor három tényezőt kell figyelembe venni: a derogáció szükségességét, az alkalmazott intézkedések arányosságát és a derogáció időtartamát - jóllehet később a Brannigan \& McBride kontra Egyesült Királyság64 ügyben az EJEB

59 Lawless v. Ireland, $\$ \$ 81-82$.

60 Svensson-Mccarthy, 1998, 295. o.

61 Questiaux, 1982, 15. o.

62 A and Others v. United Kingdom, Application no. 3455/05, Council of Europe: European Court of Human

Rights, 19 February 2009.

63 Harris-O'Boyle-Bates-Buckley, 2018, 831. o.

64 Brannigan \& McBride v. United Kingdom, [1993] Eur. Ct. H.R. (ser. A) No. 258-B. 
további tényezők számbavételét is szükségesnek ítélte meg, úgymint a derogációval érintett jogok természete és a derogációhoz vezetô események vizsgálata.

Az Egyezmény derogációs klauzulája alkalmazásának harmadik előfeltétele a részes állam egyéb nemzetközi jogi kötelezettségeivel való összeegyeztethetősége. A konzisztencia elve már a PPJNE 4. cikkének kezdeti, 1949. évi szövegváltozatában is fellelhető volt ${ }^{65}$ amely lényegében véve úgy értelmezhetô, hogy az egyéb nemzetközi jogi kötelezettségekkel való összeegyeztethetetlenség a derogációs klauzula tárgyi hatályán túlnyúlik, és nem fér bele a helyzet szükségessége által feltétlenül megkívánt mérték kategóriájába. Ezen túl egyetlen részes állam sem hivatkozhat az EJEE 15. cikkére abból a célból, hogy egyéb nemzetközi jogi kötelezettségei alól így szabaduljon, amit egyébként az Egyezmény 53. cikke is kimond. ${ }^{66}$ Arra, hogy konkrétan melyik nemzetközi jogi kötelezettségek tartoznak a 15. cikkben megemlített kötelezettségek hatálya alá, sehol sem találhatunk utalást. Az 1949. évi genfi egyezmények és az 1977. évi Első és Második Kiegészítő Jegyzőkönyveik ${ }^{67}$ minden bizonnyal idetartoznak, valamint a nemzetközi szokásjog és a civilizált nemzetek által elismert általános jogelvek, s különösképpen a nemzetközi jog jus cogens normái. E helyütt érdekességként érdemes lehet felvillantani, hogy a Ciprus kontra Törökország68 ügyben Ciprus azzal érvelt, hogy Törökország nem hivatkozhat az Egyezmény 15. cikkére, mivel a Cipruson véghezvitt katonai mûveletei agresszív háborúnak minősülnek, s mint olyanok, az ENSZ Alapokmányába ${ }^{69}$ ütköznek. Vagy például a Brannigan \& McBride kontra Egyesült Királyság ügyben a panaszosok éppen azzal érveltek, hogy az Egyesült Királyság a PPJNE 4. cikkét mint egyéb nemzetközi jogi kötelezettségét sértette meg azzal, hogy nem hirdette ki hivatalosan a szükségállapotot. Ez utóbbival azonban az EJEB nem értett egyet, mint ahogyan arra már fentebb is utaltunk a belügyminiszter képviselőházban tett nyilatkozatának megítélése kapcsán.

Fontos továbbá megjegyezni, hogy az Egyezmény négy abszolút jogot tartalmaz, amelyekkel szemben nem lehet különleges jogrend idején sem eltérést alkalmazni. Ezek az élethez való jog (2. cikk); a kínzás, embertelen, megalázó bánásmód vagy büntetés tilalma (3. cikk); a rabszolgaság és szolgaságban tartás tilalma [4. cikk (1) bekezdés] és a büntetés

65 El Zeidy, 2003, 291. o.

66 EJEE 53. cikk. Az Egyezmény egy ellenrendelkezését sem lehet úgy értelmezni, hogy az korlátozza vagy csorbítja azokat az emberi jogokat és alapvető szabadságokat, amelyeket bármely Magas Szerződő Fél joga vagy az olyan egyezmény biztosít, melynek ez a Magas Szerződő Fél részese.

67 Geneva Convention for the Amelioration of the Condition of the Wounded and Sick in Armed Forces in the Field, Aug. 12, 1949, 6 U.S.T. 3114, 75 U.N.T.S. 31; Geneva Convention for the Amelioration of the Condition of Wounded, Sick and Shipwrecked Members of Armed Forces at Sea, Aug. 12, 1949, 6 U.S.T. 3217, 75 U.N.T.S. 85; Geneva Convention Relative to the Treatment of Prisoners of War, Aug. 12, 1949, 6 U.S.T. 3316, 75 U.N.T.S. 135; Geneva Convention Relative to the Protection of Civilian Persons in Time of War, Aug. 12, 1949, 6 U.S.T. 3516, 75 U.N.T.S. 287; Protocol Additional to the Geneva Conventions of 12 August 1949, and Relating to the Protection of Victims of International Armed Conflicts, opened for signature Dec. 12, 1977, 1125 U.N.T.S. 3; Protocol Additional to the Geneva Conventions of 12 August 1949, and Relating to the Protection of Victims of Non-International Armed Conflicts, opened for signature Dec. 12, 1977, 1125 U.N.T.S. 609.

68 Cyprus v. Turkey, [1976] 4 Eur. H.R. Rep. 482, 553 (Commission report).

69 1956. évi I. törvény az Egyesült Nemzetek Alapokmányának törvénybe iktatásáról. 
kiszabásának tilalma törvényi rendelkezés nélkül [7. cikk (1) bekezdés]; és bár szövegszerü utalást nem találhatunk rá, valószínúsíthetően a megkülönböztetés tilalma (14. cikk) is a fel nem függeszthető jogok körébe tartozik, továbbá a Hatodik Kiegészítő Jegyzőkönyv 3. cikke és a Tizenharmadik Kiegészítő Jegyzőkönyv 2. cikke is a halálbüntetés eltörléséről, valamint a Hetedik Kiegészítő Jegyzőkönyv 4. cikke a kétszeres eljárás tilalmáról..$^{70}$

Az Egyezmény 15. cikk (3) bekezdése kimondja, hogy az eltérés jogával élni kívánó részes állam az Európa Tanács foótitkárának teljes körú tájékoztatást köteles adni az általa tett intézkedésekről és azok okairól. A tájékoztatási kötelezettség elő́ŕrása az EJEE-nek alapvető garanciális eleme, mivel a többi részes állam a 15. cikk alkalmazásáról a főtitkár tájékoztatása révén szerez hivatalosan tudomást, és e tájékoztatás birtokában nyílik lehetőségük arra is, hogy később esetlegesen eljárást indítsanak az eltérés jogával élő részes féllel szemben. ${ }^{71}$

A tájékoztatás szempontjából két tényezőnek van jelentősége: az időnek és a felfüggesztő nyilatkozat tartalmának. Noha az EJEE 15. cikke - a PPJNE 4. cikkéhez és az Emberi Jogok Amerikai Egyezménye 27. cikkéhez hasonlóan - szövegszerú utalást nem tartalmaz a tájékoztatás haladéktalan jellegére nézve, az esetjog arra enged következtetni, hogy e tájékoztatásnak elkerülhetô késedelem nélkül meg kell történnie. ${ }^{72}$ Ezzel párhuzamosan felmerül a kérdés, hogy vajon a tájékoztatásnak a különleges jogrend kihirdetését meg kell-e előznie. A választ ugyancsak a Lawless kontra Írország ügyben lelhetjük meg, amelyben a Bíróság jogszerûnek találta, hogy Írország a különleges jogrend bevezetése után 12 nappal nyújtotta be nyilatkozatát a főtitkárhoz. ${ }^{73} \mathrm{Az}$ Írország kontra Egyesült Királyság ügyben sem találta az EJEB egyezménysértőnek a brit kormány által 11 nappal a különleges jogrend kihirdetése után benyújtott nyilatkozatot. Ezzel szemben a görög ügyekben az Emberi Jogok Európai Bizottsága úgy látta, hogy a négy hónapos késedelem jogszerűsége már nem támasztható alá, és a görög kormány nyilatkozatának benyújtása előtt hozott intézkedéseire a 15. cikk nem szolgáltathat kimentési okot. ${ }^{74}$

Ami a felfüggesztő nyilatkozat tartalmát illeti, először is azt kell az EJEE részes államának meghatároznia, hogy az Egyezmény mely cikkeitől akar eltérni. Ezzel kapcsolatban az vethet fel további kérdéseket, hogy ha az állam az EJEE valamely cikkét a felfüggesztő nyilatkozatban nem jelöli meg, mégis később a gyakorlatban el kíván térni tőle. Az Írország kontra Egyesült Királyság ügy tényállása szerint Írország pontosan azzal érvelt, hogy az Egyesült Királyság az EJEE 14. cikkétől75 (megkülönböztetés tilalma) nem térhet el, tekintve, hogy

70 El Zeidy, 2003, 294. o.

71 El Zeidy, 2003, 295. o.

72 Oraá, 1992, 58. o.

73 Lawless v. Ireland, \$223.

74 El Zeidy, 2003, 296. o.

75 EJEE 14. cikk. A jelen Egyezményben meghatározott jogok és szabadságok élvezetét minden megkülönböztetés, például nem, faj, szín, nyelv, vallás, politikai vagy egyéb vélemény, nemzeti vagy társadalmi származás, nemzeti kisebbséghez tartozás, vagyoni helyzet, születés szerinti vagy egyéb helyzet alapján történő megkülönböztetés nélkül kell biztosítani. 
az Európa Tanács fôtitkárához benyújtott nyilatkozatában korábban e rendelkezést nem jelölte meg, ám az Emberi Jogok Európai Bizottsága a 14. cikk felől közelített az esethez, és mivel úgy találta, hogy a brit kormány nem valósított meg hátrányos megkülönböztetést, a 15. cikk esetleges sérelmét már nem vizsgálta. Ezzel szemben a testület a görög ügyekben ténylegesen is állást foglalt e kérdésben, és kimondta, hogy az EJEE 15. cikk (3) bekezdése nem ró arra irányuló abszolút kötelezettséget az államokra, hogy valamennyi, később derogációval érintett szerződéses cikket tételesen felsoroljanak. ${ }^{76} \mathrm{Az}$ Egyezmény 15. cikk (3) bekezdése a fentiek mellett arra is utal, hogy az Európa Tanács főtitkárát az eltérés keretében meghozott intézkedésekről is részletesen tájékoztatni kell: a görög kormányt részben pont emiatt marasztalták el, amikor nem nyújtott megfelelő tájékoztatást az 1968. évi alkotmány alapján megtett lépésekről. ${ }^{77} \mathrm{~A} 15$. cikk (3) bekezdése értelmében az államnak arról kell még számot adnia, hogy a derogációval milyen okból kíván élni, végül pedig arról is értesítenie kell az Európa Tanács foótitkárát, ha az elállás jogával többé már nem kíván élni, és visszatér az EJEE „békeidejứ” alkalmazásához.

\section{4. Összegzés}

A különleges jogrend jogának legfontosabb nemzetközi jogi vetülete az emberi jogi egyezmények alkalmazásának ideiglenes felfüggesztési lehetősége. Utóbbi állítás az e könyvben bemutatásra kerülő országokra különösen igaz, minthogy az európai államok esetében nemcsak a PPJNE 4. cikke, hanem az EJEE 5. cikke is lehetőséget kínál a derogációra.

Az eltérés joga, mint ahogyan az alapjogok korlátozása a belső jogban, a nemzetközi jogban is kivételes kell legyen, sőt még inkább az: egyfajta ultima ratio a szerződő államok kezében. Jóllehet a PPJNE végrehajtási mechanizmusát megtestesítő Emberi Jogok Bizottsága kötelező erejű határozatokat nem hozhat, az Emberi Jogok Európai Bíróságához hasonlóan számottevő szerepet töltött be a derogációs klauzulák értelmezésében. A két testület esetjogát sok esetben praktikus együttesen szemlélni, minthogy a PPJNE 4. cikke és az EJEE 15. cikke tartalmában - és néhol fogalomhasználatában is - nagyon hasonló, vagy éppen megegyezik. S bár a PPJNE hivatalos magyar fordítása a szükségállapot, az EJEE pedig a rendkívüli állapot terminológiáját alkalmazza, ezek tartalmilag voltaképpen azonos kategóriákat fednek le.

Egyúttal az is látható, hogy e két cikk esetjoga gyakorlati példákban nem bővelkedik legalábbis az Egyezségokmány és az Egyezmény más cikkeivel összevetve. Ennek nemcsak a vizsgált rendelkezések végsőeszköz-jellege az oka, hanem az is, hogy az egyébként különleges jogrendet kihirdető államok sokszor nem jelentik be az eltérés szándékát az ENSZ és 
az Európa Tanács fốtitkáraihoz. Ennek akkor nincs is különösebb következménye - a gyakorlati szintézisben való megjelenésen túl -, ha az állam ellen az illetékes nemzetközi fórumokhoz nem érkezik be panasz jogsértés miatt. Ellenben abban az esetben, ha a különleges jogrend kihirdetését hivatalos tájékoztatás nem előzi meg vagy haladéktalanul nem követte - és persze a panaszban foglalt egyéb feltételek is fennállnak -, az állam megsérti a PPJNE 4. vagy az EJEE 15. cikkét.

\section{Irodalomjegyzék}

BÉREs, N. (2020) A Biztonsági Tanács által a Nemzetközi Büntetóbiróság elé utalt helyzetek legfontosabb jogi problémái (PhD-értekezés). Miskolc: Miskolci Egyetem Deák Ferenc Állam- és Jogtudományi Doktori Iskola

CRAWford, J. (2002) The International Law Commission's Articles on State Responsibility [Online]. Elérhető: http://assets.cambridge.org/97805218/13532/sample/9780521813532ws.pdf (Letöltve: 2020. december 15.)

DAEs, E. (1983) The Individual's Duties to the Community and the Limitations on Human Rights and Freedoms under Article 29 of the U.D.H.R., UN Doc. E/CN.4/Sub.2/432/Rev.2 (1983) [Online]. Elérhetô: https://digitallibrary.un.org/record/52410?ln=en (Letöltve: 2020 . december 15.)

El ZEIDY, M. (2003) 'The ECHR and States of Emergency: Article 15 - A Domestic Power of Derogation from Human Rights Obligations', San Diego International Law Journal, 4(1), 277-318. o.

GÁRdos-Orosz, F. (2018) 'Alapvető jogok korlátozása' in Lamm, V. (szerk.) Emberi Jogi Enciklopédia. 1. kiadás. Budapest: HVG-ORAC

Hamilton, A. (1961) ‘The Federalist’ in Rossiter, C. (szerk.) The Federalist Papers. 1. kiadás. New York: Penguin

Harris, D., O'Boyle, M., Bates, C. Buckley (2018) Law of the European Convention on Human Rights. 1. kiadás. Oxford: Oxford University Press

IstREFI, K. (2020) To Notify or Not to Notify: Derogations from Human Rights Treaties [Online]. Elérhető: http://opiniojuris.org/2020/04/18/to-notify-or-not-to-notify-derogations-fromhuman-rights-treaties/ (Letöltve: 2020. december 15.)

Joseph, S., CASTAN, M. (2013) The International Covenant on Civil and Political Rights. 1. kiadás. Oxford: Oxford University Press

KIss, A. (1980) 'Permissible Limitations on Rights' in Henkin, L. (szerk.) The International Bill of Rights: The Covenant on Civil and Political Rights. 1. kiadás. New York: Columbia University Press

KovÁcs, P. (2016) Nemzetközi közjog. 3. kiadás. Budapest: Osiris

LAMM, V. (2018) 'ENSZ Emberi Jogi Szerződési Bizottságok' in Lamm, V. (szerk.) Emberi Jogi Enciklopédia. 1. kiadás. Budapest: HVG-ORAC 
MCGoldrick, D. (2004) 'The Interface Between Public Emergency Powers and International Law', Oxford University Press and New York University School of Law, 2(2), 380-429. o.

NowAK, M. (2005) UN Covenant on Civil and Political Rights. 1. kiadás. Kehl am Rhein: Engel

OraÁ, J. (1992) Human Rights in States of Emergency in International Law. 1. kiadás. Oxford: Oxford University Press

Questiaux, N. (1982) Question of the Human Rights of Persons Subjected to any Form of Detention or Imprisonment: Study of the Implications for Human Rights Recent Developments Concerning Situations Known as States of Siege or Emergency, U.N. Doc. E/CN.41Sub.2/1982/15 [Online]. Elérhető: www.refworld.org/docid/3boofo8960.html (Letöltve: 2020. december 15.)

RAIsz, A. (2009) Az Emberi Jogok Európai és Amerikaközi Bíróságának egymásra hatása (PhDértekezés). Miskolc: Miskolci Egyetem Deák Ferenc Állam-és Jogtudományi Doktori Iskola SvensSON-MCCARTHy, A. (1998) The International Law of Human Rights and States of Exception. 1. kiadás. Leiden: Brill

Till, Sz. P. (2020) Freedom of European National Constitutions to Regulate Emergencies. (Comparative Study on the Hungarian Structure of Special Legal Orders). Budapest: Hungarian Society for Military Law and Law of War 